\title{
Lymphocyte subsets in human immunodeficiency virus-unexposed Brazilian individuals from birth to adulthood
}

\author{
Maria Isabel de Moraes-Pinto ${ }^{1 /+}$, Erika Ono ${ }^{1}$, Elisângela C Santos-Valente', \\ Liziane C Almeida', Paula Rosemberg de Andrade², Maria Isabel Saraiva Dinelli', \\ Amélia M Nunes dos Santos ${ }^{3}$, Reinaldo Salomão ${ }^{4}$
}

\begin{abstract}
${ }^{1}$ Disciplina de Infectologia Pediátrica ${ }^{3}$ Disciplina de Pediatria Neonatal, Departamento de Pediatria ${ }^{4}$ Disciplina de Infectologia, Departamento de Medicina, Universidade Federal de São Paulo, São Paulo, SP, Brasil ${ }^{2}$ Centro Assistencial Cruz de Malta, São Paulo, SP, Brasil
\end{abstract}

\begin{abstract}
Ethnic origin, genetics, gender and environmental factors have been shown to influence some immunologic indices, so that development of reference values for populations of different backgrounds may be necessary. We have determined the distribution of lymphocyte subsets in healthy Brazilian individuals from birth to adulthood. Lymphocyte subsets were determined using four-colour cytometry in a cross-sectional study of 463 human immunodeficiency virus-unexposed children and adults from birth through 49 years of age. Lymphocyte subsets varied according to age, as previously observed in other studies. However, total $\mathrm{CD}^{+} \mathrm{T}$ cell numbers were lower than what was described in the Pediatric AIDS Clinical Trials Group P1009 (PACTG P1009), which assessed an American population of predominantly African and Hispanic backgrounds until the 12-18 year age range, when values were comparable. Naïve percentages and absolute values of $C D 8^{+} T$ cells, as assessed by CD45RA expression, were also lower than the PACTG P1009 data for all analysed age ranges. CD38 expression on both $C D 4^{+}$and CD $8^{+} T$ cells was lower than the PACTG P1009 values, with a widening gap between the two studies at older age ranges. Different patterns of cell differentiation seem to occur in different settings and may have characteristic expression within each population.
\end{abstract}

Key words: lymphocyte subsets - flow cytometry - immunodiagnostics - clinical profile - HIV

Peripheral lymphocytes are known to vary in number and percentage from birth until death. The first studies on the subject dealt with small sample sizes and a limited number of cell subsets were analysed (Yachie et al. 1981, Yanase et al. 1986, Wiener et al. 1990, ErkellerYuksel et al. 1992, Calado et al. 1999). The development of new laboratory techniques, the discovery of different cell subsets and the use of various cell markers have led to a constant need to update previous reference values. Moreover, different variables have proved to interfere with normal ranges of all of these cell subsets.

Ethnic origin, genetics, gender and environmental factors have been shown to influence some immunologic indices, so that the development of reference values for populations of different backgrounds may be necessary to improve diagnosis and follow-up of individuals with chronic diseases and an altered immune system.

Previous studies have found that exclusively-breastfed infants had a higher thymic index than partially-breastfed or formula-fed infants as assessed by sonography (Hasselbalch et al. 1997). Additionally, CD ${ }^{+}$T cell numbers were higher among exclusively-breastfed children, who also

doi: 10.1590/0074-0276140182

Financial support: FAPESP (01/11011-6)

+ Corresponding author: m.isabelmp@uol.com.br

Received 29 May 2014

Accepted: 27 October 2014 had a higher thymic index (Jeppensen et al. 2004). The authors speculated on the potential for both current and long-term immune-modulating effects of human milk on the developing immune system (Jeppensen et al. 2004).

Because more intense and frequent modifications occur in the developing immune system, the paediatric age range is the period of life when more changes are observed. Hence, the need for immunologic reference values that do vary across the neonatal period, infancy, childhood and adolescence is undisputable.

In the present study, we have determined the distribution of lymphocyte subsets in healthy Brazilian neonates, infants, children, adolescents and adults.

\section{SUBJECTS, MATERIALS AND METHODS}

Patients and study design - This study was an observational, cross-sectional assessment of lymphocyte subsets in human immunodeficiency virus (HIV)-unexposed healthy children from birth to 49 years of age. The protocol was approved by the Ethical Committee of the Federal University of São Paulo (UNIFESP), in São Paulo, Brazil. All individuals or parents - in the case of individuals below 18 years of age - gave written informed consent prior to enrolment in the study.

Inclusion criteria were: neonatal weight of $2,500 \mathrm{~g}$ or more, having no chronic diseases or previous clinical findings suggestive of immune compromise (e.g., meningitis, pneumonia, repetitive acute upper respiratory infections or diarrhoea), having no acute disease in the previous seven days before blood collection, using no medication other than vitamins, not being pregnant and not being HIV-exposed. 

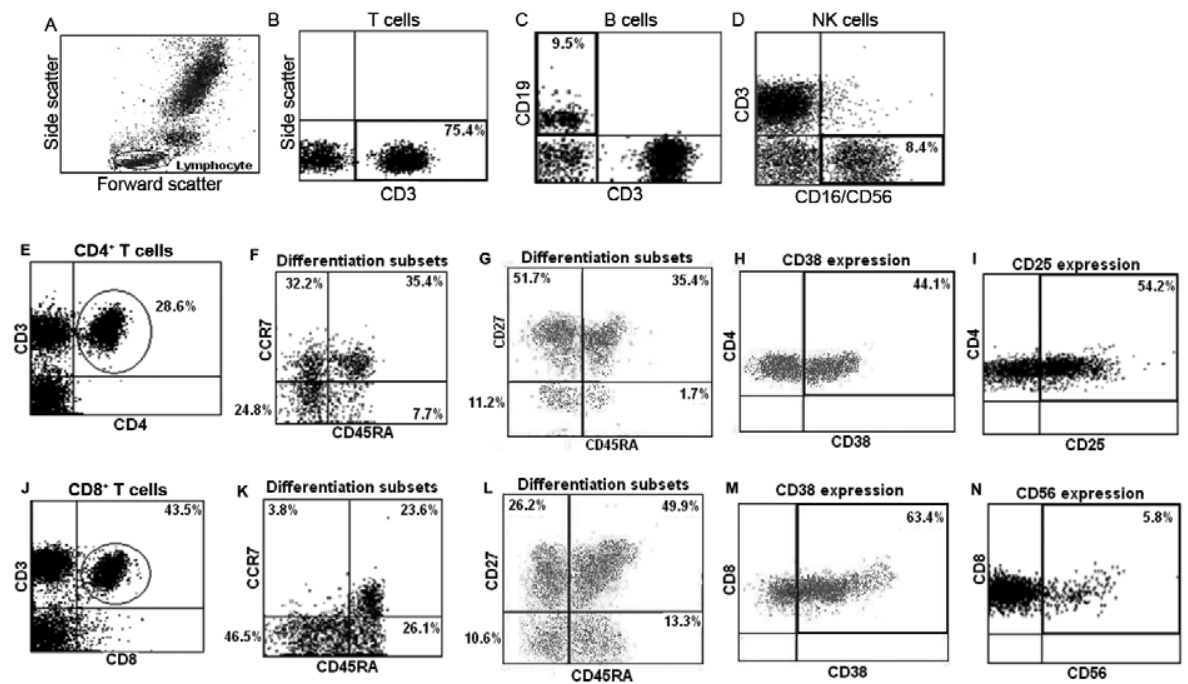

Fig. 1: illustrative example of flow cytometry plots for data analysis. Lymphocytes were selected on the side scatter/forward scatter plot with a gate as shown in A. T cells were identified from the gate of lymphocytes as $\mathrm{CD}^{+}(\mathrm{B})$, B cells, as $\mathrm{CD}^{-} \mathrm{CD} 19^{+}(\mathrm{C})$ and natural killer (NK) cells, as $\mathrm{CD}^{-} \mathrm{CD}^{-} 6^{+} / \mathrm{CD} 6^{+}$(D). $\mathrm{CD}^{+} \mathrm{T}$ cells were identified from the gate of lymphocytes as $\mathrm{CD}^{+} \mathrm{CD}^{+}(\mathrm{E})$ and then separated in differentiation subsets using CD45RA/CCR7 (F) or CD45RA/CD27 markers (G); CD38 and CD25 expression were evaluated on CD4 ${ }^{+} \mathrm{T}$ cells in $\mathrm{H}$ and I, respectively. $\mathrm{CD} 8^{+} \mathrm{T}$ cells were identified from the gate of lymphocytes as $\mathrm{CD} 3^{+} \mathrm{CD} 8^{+}(\mathrm{J})$ and then separated in differentiation subsets using $\mathrm{CD} 45 \mathrm{RA} / \mathrm{CCR} 7$ (K) or CD45RA/CD27 markers (L); CD38 and CD56 expression were evaluated on CD8 ${ }^{+} \mathrm{T}$ cells in $\mathrm{M}$ and $\mathrm{N}$, respectively. Isotypic controls were employed to set the gates in F-I, K-N plots.

Age strata were organised as follows: cord blood, one91 days old (0-3 months), 92-182 days old (3-6 months), 183-364 days old (6-12 months), from the first birthday to the day before the second birthday (1-2 years), from the second birthday to the day before the sixth birthday (2-6 years), from the sixth birthday to the day before the 12th birthday (6-12 years), from the 12th birthday to the day before the 19th birthday (12-18 years) and from the 19th birthday to the day before the 49th birthday (19-48 years).

For each age strata, effort was made to have an equal distribution of male and female subjects.

Data regarding the period of exclusive and non-exclusive breastfeeding were also collected at study entry up to the 12-18 year age stratum.

Cord blood collection was performed in two neonatal units from hospitals associated with UNIFESP. Individuals from all other age strata were assessed at São Paulo Hospital and Centro Assistencial Cruz de Malta, in São Paulo. Four hundred and sixty-three subjects participated in the study, comprising a minimum of 50 individuals per age group.

Blood collection - Cord blood $(10 \mathrm{~mL})$ was collected from the umbilical vein. For all other age strata, a $5-\mathrm{mL}$ blood sample of peripheral blood was collected. Samples were put into ethylenediamine tetraacetic acid-treated vacuum tubes for complete blood counts $(\mathrm{CBC})$ and phenotypic analysis of peripheral blood mononuclear cell subsets using flow cytometry assays.

$C B C$ - All samples were tested using ADVIA 120 automatic counter (Bayer HealthCare, Germany). When indicated, a slide smear was performed for manual count by a trained staff.
Flow cytometry analysis - Cord and peripheral blood mononuclear cells were assessed by flow cytometry (FACSCalibur, BD Biosciences, USA) within $18 \mathrm{~h}$ of blood collection and analysed using CellQuest software (BD Biosciences). Four-colour phenotypic characterisations were performed in fresh blood using a lyse-wash protocol. Appropriate isotype controls (IgG1-FITC, IgG1-PE, IgG1-APC, IgG2a-PE) (BD Biosciences) were used to evaluate non-specific staining. For each sample, multiparametric data were acquired for 10,000 events.

Cell numbers per cubic millilitre of blood were obtained using the lymphocyte counts from the CBC.

The following monoclonal antibody (MAb) (all from BD Biosciences) combinations were used: $\mathrm{CD} 4^{+}$ $\mathrm{T}$ lymphocytes and differentiation subsets using CD45RA and CCR7. Using CD3-APC, CD4-PerCP, CD45RA-FITC and CCR7-PE, T cell subsets were defined as naïve, $\mathrm{CD}_{3}^{+} \mathrm{CD}^{+} \mathrm{CD} 45 \mathrm{RA}^{+} \mathrm{CCR} 7^{+}$, central memory, $\mathrm{CD}^{+} \mathrm{CD}^{+} \mathrm{CD} 45 \mathrm{RA}^{-} \mathrm{CCR} 7^{+}$, effector memory, $\mathrm{CD}^{+} \mathrm{CD}^{+}{ }^{+} \mathrm{CD} 45 \mathrm{RA}^{-} \mathrm{CCR} 7-$, and effector, $\mathrm{CD}^{+}{ }^{+} \mathrm{CD} 4{ }^{+} \mathrm{CD} 45 \mathrm{RA}^{+} \mathrm{CCR} 7-$ (Maecker et al. 2012).

$C D 4^{+} T$ lymphocytes and differentiation subsets using CD45RA and CD27 - Using CD3-APC, CD4-PerCP, CD45RA-FITC and CD27-PE, T cell subsets were defined as naïve, $\mathrm{CD} 3{ }^{+} \mathrm{CD} 4{ }^{+} \mathrm{CD} 45 \mathrm{RA}{ }^{+} \mathrm{CD} 27^{+}$, effector memory, $\mathrm{CD}^{+}{ }^{+} \mathrm{CD} 4{ }^{+} \mathrm{CD} 45 \mathrm{RA}^{-\mathrm{CD}} 27^{+}$and $\mathrm{CD}^{+}{ }^{+} \mathrm{CD} 4{ }^{+} \mathrm{CD} 45 \mathrm{RA}^{-}$

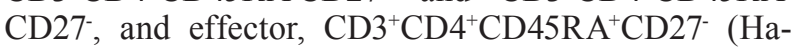
mann et al. 1997).

$\mathrm{CD} 8^{+} \mathrm{T}$ lymphocytes were characterised in the same way for differentiation subsets by substituting CD4PerCP MAb for CD8-PerCP MAb (Hamann et al. 1997, Maecker et al. 2012). 
$\mathrm{CD}^{+} \mathrm{T}$ lymphocyte activation - Using CD3-APC, CD4-PerCP, CD38-FITC and CD25-PE, CD38 and CD25 expression were evaluated as the percentage of positive $\mathrm{CD} 3^{+} \mathrm{CD} 4^{+} \mathrm{T}$ cells for each marker.

$C D 8^{+} T$ lymphocyte activation - Using CD3-APC, CD8-PerCP and CD38-FITC, CD38 expression was evaluated as the percentage of positive $\mathrm{CD} 3^{+} \mathrm{CD} 8^{+} \mathrm{T}$ cells.

$C D 8^{+} T$ lymphocytes with cytolytic effector function - Using CD3-APC, CD8-PerCP and CD56-PE, CD56 expression was evaluated as the marker associated with cytolytic function (Pittet et al. 2000, Poonia \& Pauza 2014).

B lymphocytes - Using CD3-APC and CD19-FITC, B lymphocytes were identified as $\mathrm{CD} 3{ }^{-} \mathrm{CD} 19^{+}$cells.

Natural killer (NK) cells - Using CD3-APC, CD45PerCP, CD16-PE and CD56-PE, NK cells were quantified by the $\mathrm{CD} 45^{+} \mathrm{CD} 3{ }^{-} \mathrm{CD} 56^{+} \mathrm{CD} 16^{+}$phenotype.

Fig. 1 shows an illustrative example of flow cytometry plots used for data analysis.

Statistical analysis - Data were analysed using Minitab 15.1 (Minitab, USA) and Stata 7.0 (Stata, USA). Percentiles (10th, median and 90th) of end-point distributions are based on percentiles of observed data. Comparison with Pediatric AIDS Clinical Trials Group P1009 (PACTG P1009) data (Shearer et al. 2003) was performed by measuring the median $95 \%$ confidence intervals for each parameter within age strata from zero-three months up to 12-18 years and comparing them with median values from the corresponding data from Shearer et al. (2003). The level of significance was set at $\mathrm{p}<0.05$.

\section{RESULTS}

Four hundred and sixty-three individuals participated in the study. The characteristics of study subjects are summarised in Table I. They reflect the Brazilian population, where the majority of children are exclusively breastfed during the first three or four months. After the introduction of formula or solid food, many are still partially breastfed during the second semester of life.

Table II presents subset percentages of peripheral blood lymphocytes and Table III depicts cell subset counts of peripheral blood lymphocytes in different age strata from healthy Brazilian children, adolescents and adults.

During the first two years one observes an increase in absolute numbers of $\mathrm{CD} 4^{+} \mathrm{T}, \mathrm{CD} 8^{+} \mathrm{T}$ and $\mathrm{B}$ lymphocytes, with a subsequent reduction in numbers from two years on for $\mathrm{CD}^{+} \mathrm{T}$ and $\mathrm{CD} 8^{+} \mathrm{T}$ and from six months on for B cells. NK cell numbers, in contrast, show a progressive decrease from birth and stabilise around the two-six year age strata.

With respect to $\mathrm{T}$ cell differentiation, there is a progressive decline in naïve $\mathrm{T}$ cells, but to a variable extent depending on the cell markers utilised (CD45RA/CCR7, CD45RA/CD27 or CD45RA). CD38 expression shows a faster decrease in $\mathrm{CD} 8^{+} \mathrm{T}$ cells than in $\mathrm{CD} 4^{+} \mathrm{T}$ cells. $\mathrm{CD} 25$ expression in $\mathrm{CD}^{+} \mathrm{T}$ cells increases only in percentage from the two-six year age strata on.

The $\mathrm{CD}^{2} 6^{+} \mathrm{T}$ cell subset percentage is stable up to the one-two year strata and increases from then on.

Results from the present study were compared with data from PACTG P1009 (Shearer et al. 2003). Parameters compared were those that were tested by both studies

TABLE I

Demographic data and breastfeeding information of study participants

\begin{tabular}{|c|c|c|c|c|c|c|c|c|c|}
\hline & $\begin{array}{l}\text { Cord } \\
\text { blood }\end{array}$ & $\begin{array}{l}0-3 \\
\text { months }\end{array}$ & $\begin{array}{l}\text { 3-6 } \\
\text { months }\end{array}$ & $\begin{array}{c}\text { 6-12 } \\
\text { months }\end{array}$ & $\begin{array}{c}1-2 \\
\text { years }\end{array}$ & $\begin{array}{c}2-6 \\
\text { years }\end{array}$ & $\begin{array}{c}6-12 \\
\text { years }\end{array}$ & $\begin{array}{l}12-18 \\
\text { years }\end{array}$ & $\begin{array}{l}19-48 \\
\text { years }\end{array}$ \\
\hline Age strata (n) & 53 & 51 & 50 & 53 & 50 & 55 & 50 & 50 & 51 \\
\hline $\begin{array}{l}\text { Feminine gender } \\
{[\mathrm{n}(\%)]}\end{array}$ & $10(18.9)$ & $19(37.2)$ & $27(54)$ & $24(45)$ & $23(46)$ & $22(40)$ & $29(58)$ & $22(44)$ & $25(49)$ \\
\hline $\begin{array}{l}\text { Exclusive breastfeeding at assessment } \\
{[\mathrm{n}(\%)]}\end{array}$ & NA & $39(77)$ & $20(40)$ & - & - & - & - & - & $\mathrm{NC}$ \\
\hline $\begin{array}{l}\text { Partial breastfeeding at assessment } \\
{[\mathrm{n}(\%)]}\end{array}$ & NA & $10(20)$ & $14(28)$ & - & - & - & - & - & $\mathrm{NC}$ \\
\hline $\begin{array}{l}\text { Total exclusive breastfeeding time } \\
\text { (mean } \pm \mathrm{SD} \text { ) (months) }\end{array}$ & NA & - & - & $3.6 \pm 2.7$ & $4.7 \pm 2.5$ & $3.5 \pm 4.0$ & $4.1 \pm 2.9$ & $4.2 \pm 2.9$ & $\mathrm{NC}$ \\
\hline $\begin{array}{l}\text { Total breastfeeding time } \\
(\text { mean } \pm \mathrm{SD}) \text { (months) }\end{array}$ & NA & - & - & $5.4 \pm 2.8$ & $8.8 \pm 5.7$ & $8.3 \pm 9.7$ & $12.7 \pm 13.2$ & $9.2 \pm 9.5$ & $\mathrm{NC}$ \\
\hline $\begin{array}{l}\text { Children with formula only from birth } \\
{[\mathrm{n}(\%)]}\end{array}$ & NA & $2(4)$ & None & None & $2(1)$ & $6(11)$ & $1(0.5)$ & $5(10)$ & $\mathrm{NC}$ \\
\hline
\end{tabular}

NA: not applicable; NC: data not collected; SD: standard deviation. 


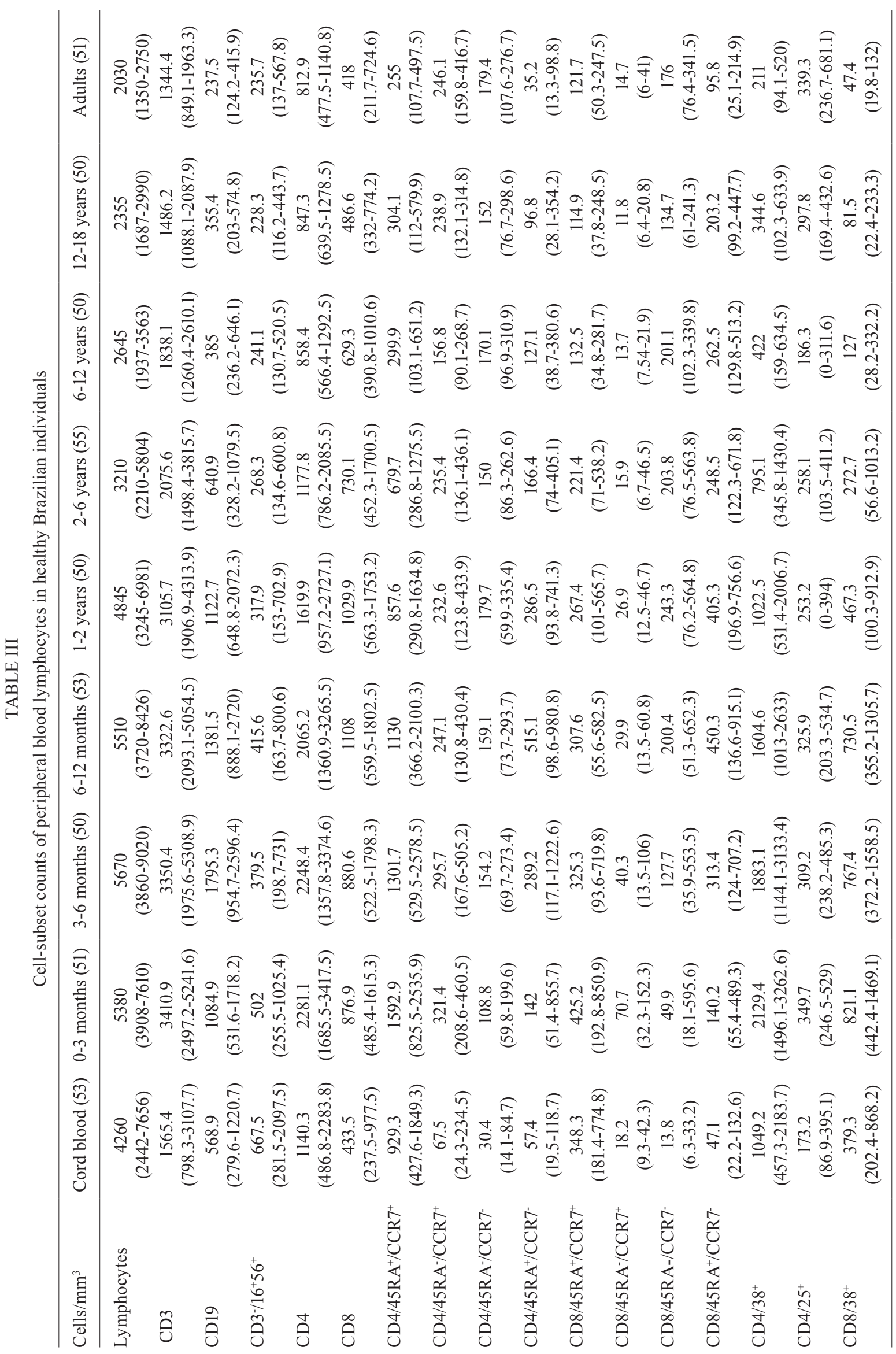




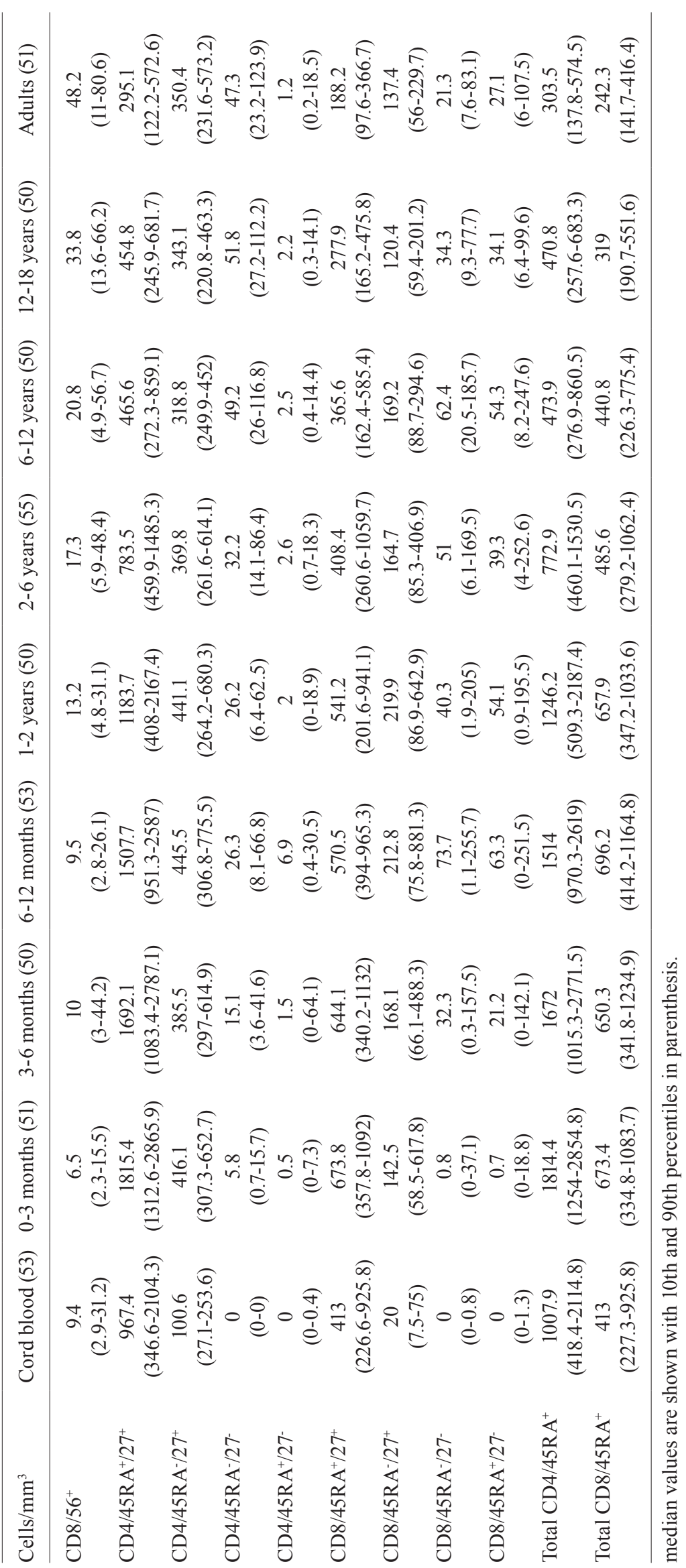


Total lymphocytes

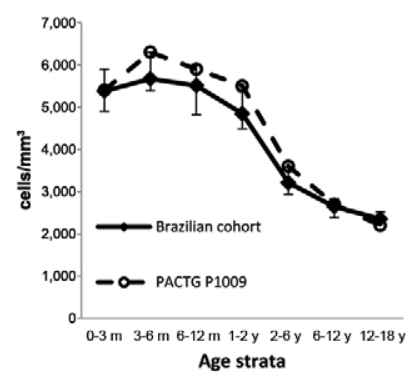

CD3* T cells

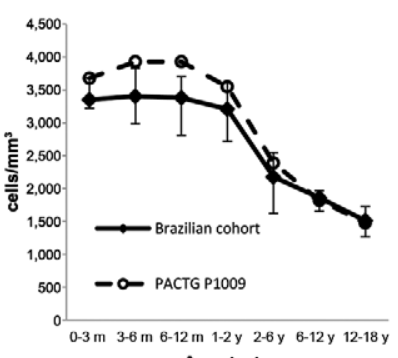

Age strata

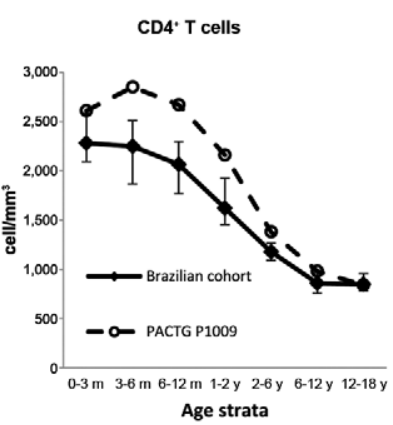

B cells

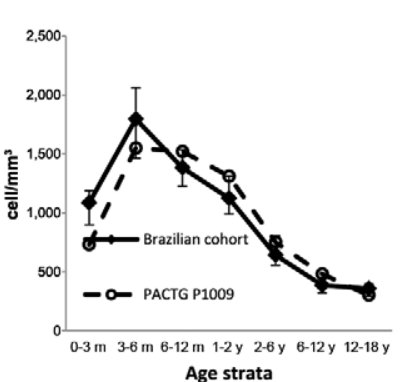

CD8* T cells

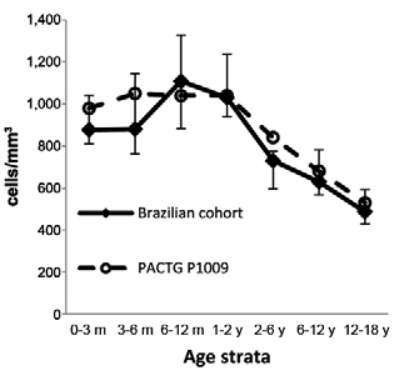

NK cells

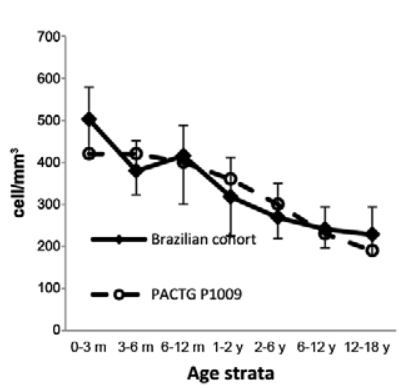

Fig. 2: total lymphocyte, $\mathrm{CD}^{+} \mathrm{T}$ cell, $\mathrm{CD} 4^{+} \mathrm{T}$ cell, $\mathrm{CD}^{+} \mathrm{T}$ cell, $\mathrm{B}$ cell and natural killer $(\mathrm{NK})$ cell counts in American children and adolescents from Pediatric AIDS Clinical Trials Group P1009 (PACTG P1009) study and from Brazilian children and adolescents distributed in similar age strata. Data are presented in median values for each age stratum, with $95 \%$ confidence interval (CI) shown for the Brazilian cohort. Study data are considered statistically different if median values from PACTG P1009 study are not included in the 95\% CI of the Brazilian cohort. m: months; y: years.

CD4*CD45RA* cells

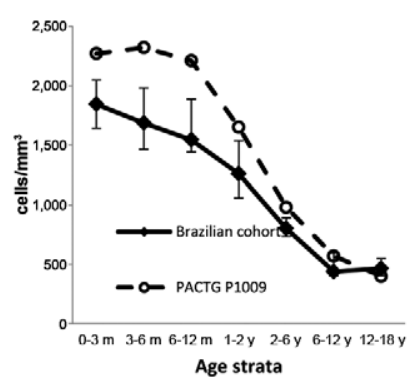

Age strata

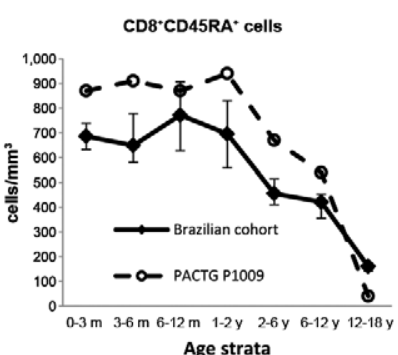

CD4'CD45RA'

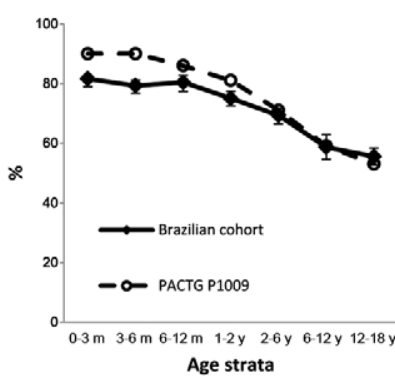

CD8*CD45RA*

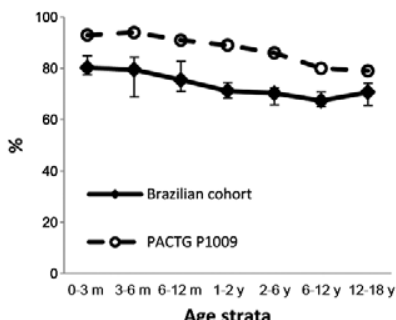

CD4+CD38
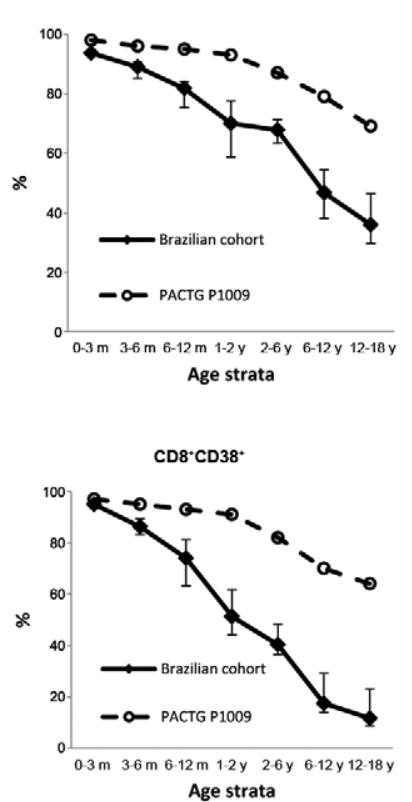

Fig. 3: $\mathrm{CD}^{+} \mathrm{T}$ and $\mathrm{CD} 8^{+} \mathrm{T}$ cells in American children and adolescents from Pediatric AIDS Clinical Trials Group P1009 (PACTG P1009) study and in Brazilian children and adolescents distributed in similar age strata. Cells are analysed according to percentage and absolute values of naïve subsets $\left(\mathrm{CD} 45 \mathrm{RA}^{+}\right)$and percentage of $\mathrm{CD} 38^{+}$cells. Study data are considered statistically different if median values from PACTG P1009 study are not included in the $95 \%$ confidence interval of the Brazilian cohort. m: months; y: years. 
within age strata from zero-three months to 12-18 years. They were: total lymphocyte, $\mathrm{CD}^{+} \mathrm{T}$ cell, $\mathrm{CD} 4^{+} \mathrm{T}$ cell, $\mathrm{CD} 8^{+} \mathrm{T}$ cell, B cell and NK cell counts (Fig. 2), $\mathrm{CD}^{+} \mathrm{T}$ cells and $\mathrm{CD} 8^{+} \mathrm{T}$ cells were also compared by percentage and absolute values of naïve subsets $\left(C D 45 \mathrm{RA}^{+}\right)$and percentage of $\mathrm{CD} 38^{+}$cells (Fig. 3).

Brazilian $\mathrm{CD}^{+} \mathrm{T}$ cell numbers were lower than those from the PACTG P1009 (Shearer et al. 2003) up to adolescence. Naïve $\mathrm{CD} 4^{+}$and $\mathrm{CD} 8^{+} \mathrm{T}$ cell percentages were also lower in Brazilian children, but percentages were comparable to the American study in older children and adolescents. $\mathrm{CD} 38$ expression on $\mathrm{CD} 4^{+}$and $\mathrm{CD} 8^{+} \mathrm{T}$ cells, in contrast, showed an intense reduction among Brazilian children and adolescents with a progressive difference when compared to individuals from the PACTG P1009 (Shearer et al. 2003).

\section{DISCUSSION}

We have assessed the distribution of lymphocyte subsets in healthy Brazilian neonates, infants, children, adolescents and adults. Individuals were not separated according to different race-ethnic groups due to the very mixed race characteristic of the Brazilian population. Demographic data showed a predominantly breastfed population with very rare $(0-11 \%)$ exclusively formula-fed children.

Total lymphocyte, $\mathrm{CD}^{+} \mathrm{T}$ cell, $\mathrm{CD} 8^{+} \mathrm{T}$ cell, $\mathrm{B}$ cell and NK cell numbers showed similar values in age strata as depicted by Shearer et al. (2003) when assessing an American population with predominantly African and Hispanic backgrounds. $\mathrm{CD}^{+} \mathrm{T}$ cell counts, in contrast, were lower than Shearer et al.'s (2003) values up to the 12-18 year age range when values were then comparable.

Brazilian median cord blood values $/ \mathrm{mm}^{3}$ were also lower than Ethiopians' with respect to $\mathrm{CD}^{+} \mathrm{T}(1,565$ vs. $2,640), \mathrm{CD}^{+} \mathrm{T}(1,140$ vs. 1,816$)$ and $\mathrm{CD} 8^{+} \mathrm{T}$ cells $(433$ vs. 730$)$. In contrast, total lymphocyte $(4,260$ vs. 3,714$)$, B (569 vs. 528$)$ and NK cell numbers (668 vs. 668 ) were comparable to Ethiopians' (Tsegaye et al. 2003).

When compared with 39 British term infants at six-eight weeks of life, our data from the zero-three month age range showed low total lymphocytes $(5,380$ vs. 5,902$), \mathrm{CD}^{+} \mathrm{T}$ cells $(3,411$ vs. 4,098$), \mathrm{CD}^{+} \mathrm{T}$ cells $(2,281$ vs. 2,946$)$ and $B$ cells $(1,085$ vs. 1,481$)$, but similar $\mathrm{CD} 8^{+} \mathrm{T}$ cells (877 vs. 971$)$ and higher NK cells (502 vs. 277 ) in the Brazilian cohort (Berrington et al. 2005).

Lugada et al. (2004), studying a Ugandan population, found that the decline in $\mathrm{CD}^{+}$and $\mathrm{CD}^{+} \mathrm{T}$ cells extended throughout childhood and adolescence, which is different from other western studies (Shearer et al. 2003).

Other studies performed in African countries have noted low $\mathrm{CD}^{+} \mathrm{T}$ cell numbers in comparison to western countries. That was the case for Sagnia et al. (2011), who stratified children from birth to six years in a similar way as Shearer et al. (2003) and our group. $\mathrm{CD}^{+} \mathrm{T}$ cells $/ \mathrm{mm}^{3}$ were very close to our median results (cord, 1,552; 0-3 months, 2001; 3-6 months, 2,133; 6-12 months, $2,252$; $1-2$ years, 1,$667 ; 2-6$ years, 1,289$)$. Another study performed in Malawi also showed low $\mathrm{CD}^{+} \mathrm{T}$ cell numbers among children compared to Shearer et al. (2003), but similar $\mathrm{CD}^{+} \mathrm{T}$ cell numbers among adults (Mandala et al. 2010). In contrast, Abdelltef et al. (2014) evaluated a Sudanese population and found that low $\mathrm{CD} 4^{+} \mathrm{T}$ cells were present even in adults.

When $\mathrm{CD}^{+}$and $\mathrm{CD} 8^{+} \mathrm{T}$ cell subsets from our Brazilian group were assessed using CD45RA and CCR7 markers, naïve cells $\left(\mathrm{CD} 45 \mathrm{RA}^{+} \mathrm{CCR} 7^{+}\right)$were lower for all age strata both in percentage and absolute values when compared with Shearer et al.'s (2003) data using CD45RA and CD62L markers.

We have also studied $\mathrm{CD} 4^{+}$and $\mathrm{CD} 8^{+} \mathrm{T}$ cell subsets using CD45RA and CD27 markers. Naïve cells defined as $\mathrm{CD}^{2} 5 \mathrm{RA}^{+} \mathrm{CD} 27^{+}$showed higher percentages than CD45RA ${ }^{+} \mathrm{CCR} 7^{+}$naïve cells.

However, when CD45RA ${ }^{+}$naïve cells were compared to Shearer et al.'s (2003) data, both percentages and absolute values for $\mathrm{CD}^{+} \mathrm{T}$ cells were lower for all age strata that were available for comparison. When $\mathrm{CD} 4^{+} \mathrm{T}$ cells were analysed in the same way, the percentage of naïve cells were similar from the two-six year range onwards and absolute values were similar to Shearer's from the six-12 year stratum onwards.

The activation marker available for comparison in the literature was mainly CD38. Our results showed a steady decline in positive cells from birth through adulthood, much in accordance with what was found by McCloskey et al. (1997) and much lower than those reported by Shearer et al. (2003) for both $\mathrm{CD} 4^{+}$and $\mathrm{CD}^{+} \mathrm{T}$ cells.

In Thailand, researchers also observed different $\mathrm{CD} 38$ expression on $\mathrm{CD} 8^{+} \mathrm{T}$ cells when compared with Caucasians; Thai HIV-negative individuals had twice the CD38 expression of Caucasians (Sukwit et al. 2005).

Tiba et al. (2011) in Burkina Faso, Africa, noted different expression of $\mathrm{CD} 38$ on $\mathrm{CD} 8^{+} \mathrm{T}$ cells among healthy individuals. The authors hypothesised that environmental exposure may influence peripheral blood $\mathrm{T}$ cell activation. In their study, adults from a rural setting had higher expression of CD38 than those from an urban setting. In their opinion, both the expression of activation markers and the distribution pattern of $\mathrm{T}$ cell differentiation subsets may be a surrogate parameter for environmentally-driven immune senescence.

The peculiar CD38 expression in the Brazilian cohort was probably the most striking of our results, because lower levels persisted until adulthood in comparison with Shearer et al. (2003). CD38 is a multifunctional ectoenzyme that uses nicotinamide adenine dinucleotide (NAD) as a substrate to generate second messengers. It was identified as one of the main cellular NADases in mammalian tissues and appears to regulate cellular levels of NAD in multiple tissues and cells. NAD participates in multiple physiological processes, such as insulin secretion, control of energy metabolism, neuronal and cardiac cell survival, airway constriction, asthma, aging and longevity (Chini 2009). CD38 is a powerful disease marker for human leukaemias and myelomas, is directly involved in the pathogenesis and outcome of chronic lymphocytic leukaemia (Malavasi et al. 2008) and is a marker of immune activation in HIV infection (Zaccarelli-Filho et al. 2007).

In line with the influence of dietary habits on the development of the immune system, formula-fed infants evaluated at the age of four months had higher absolute 
counts of $\mathrm{CD} 4^{+} \mathrm{CD} 38^{+} \mathrm{T}$ cells than breastfed infants (Pozo-Rubio et al. 2013). The fact that lower $\mathrm{CD} 4^{+} \mathrm{CD} 38^{+} \mathrm{T}$ cell counts were found in breastfed children supports the enhancing effect of breastfeeding on lymphocyte maturation and may explain the low $\mathrm{CD} 38$ expression on $\mathrm{T}$ cells from Brazilian children.

The other possible concern refers to $\mathrm{CD}^{+} \mathrm{T}$ cell values: they were statistically lower than Shearer et al.'s (2003) up to the six-12 year age range. This finding may lead to a misclassification of Brazilian children as immunocompromised if the Centers for Disease Control and Prevention, Division of Pediatric Human Immunodeficiency Virus classification is used. Indeed, some individuals within the three-six months, six-12 months, one-two years and two-six years age ranges would be classified as "evidence of moderate suppression" (category 2) if we consider the 1994 revised classification system for HIV infection in children less than 13 years of age based on $\mathrm{CD}^{+} \mathrm{T}$ cell numbers (CDC 1994). However, even Shearer et al.'s absolute values would have some children in the two-six year age range classified as "evidence of moderate suppression" (category 2) if the same Pediatric HIV classification from CDC (1994) was employed.

Interestingly, older age strata tend to vary less among different studies. These findings suggest that the immune system matures in different patterns in diverse populations, probably due to diverse genetic backgrounds, but also due to varied antigenic stimuli during infancy and childhood. This is especially relevant currently as the environmental influence is noted on the differentiation of the immune system (Sommer \& Bäckhed 2013). Unfortunately, not all studies subdivide samples into similar age ranges, which makes comparisons between studies more difficult.

Moreover, cells are assessed in varied ways, for instance, with respect to differentiation, increasing the problem of comparison between studies. Standardising immunophenotyping is the first step to allow a comparison between results from different research groups (Maecker et al. 2012). However, in an effort to better understand the immune system, one needs to establish what the limits between health and disease are in different settings and age strata.

In summary, our results are consistent with previous reports suggesting that various lymphocyte subsets show similarities across different populations, but different patterns of cell populations are also present. $\mathrm{CD}^{+}$ $\mathrm{T}$ cell counts are probably the most frequently reported divergent parameter.

\section{ACKNOWLEDGEMENTS}

To Erika Antunes, for technical assistance.

\section{REFERENCES}

Abdelltef HM, Osman IM, Hilmi ZA, Altayeb OA 2014. The reference ranges for lymphocytes subsets of healthy adults individuals by immunophenotyping. Aust J Basic Appl Sci 8: 514-520.

Berrington JE, Barge D, Fenton AC, Cant AJ, Spickett GP 2005. Lymphocyte subsets in term and significantly preterm UK infants in the first year of life analysed by single platform flow cytometry. Clin Exp Immunol 140: 289-292.
Calado RT, Garcia AB, Falcão RP 1999. Age-related changes of immunophenotypically immature lymphocytes in normal human peripheral blood. Cytometry 38: 133-137.

CDC - Centers for Disease Control and Prevention 1994. 1994 revised classification system for human immunodeficiency virus infection in children less than 13 years of age. MMWR Recomm Rep 43: 1-10.

Chini EN 2009. CD38 as a regulator of cellular NAD: a novel potential pharmacological target for metabolic conditions. Curr Pharm Des 15: 57-63.

Erkeller-Yuksel FM, Deneys V, Yuksel B, Hannet I, Hulstaert F, Hamilton C, Mackinnon H, Stokes LT, Munhyeshuli V, Vanlangendonck F, de Bruyère M, Bach BA, Lydyard PM 1992. Age-related changes in human blood lymphocyte subpopulations. $J$ Pediatr 120: $216-222$.

Hamann D, Baars PA, Rep MH, Hooibrink B, Kerkhof-Garde SR, Klein MR, van Lier RA 1997. Phenotypic and functional separation of memory and effector human $\mathrm{CD} 8^{+} \mathrm{T}$ cells. $J$ Exp Med 186: $1407-1418$.

Hasselbalch H, Jeppesen DL, Ersbøll AK, Engelmann MD, Nielsen MB 1997. Thymus size evaluated by sonography. A longitudinal study on infants during the first year of life. Acta Radiol 38: 222-227.

Jeppesen DL, Hasselbalch H, Lisse IM, Ersbøll AK, Engelmann MD 2004. T-lymphocyte subsets, thymic size and breastfeeding in infancy. Pediatr Allergy Immunol 15: 127-132.

Lugada ES, Mermin J, Kaharuza F, Ulvestad E, Were W, Langeland N, Asjo B, Malamba S, Downing R 2004. Population-based hematologic and immunologic reference values for a healthy Ugandan population. Clin Diagn Lab Immunol 11: 29-34.

Maecker HT, McCoy JP, Nussenblatt R 2012. Standardizing immunophenotyping for the Human Immunology Project. Nat Rev Immunol 12: 191-200.

Malavasi F, Deaglio S, Funaro A, Ferrero E, Horenstein AL, Ortolan E, Vaisitti T, Aydin S 2008. Evolution and function of the ADP ribosyl cyclase/CD38 gene family in physiology and pathology. Physiol Rev 88: 841-886.

Mandala WL, MacLennan JM, Gondwe EN, Ward SA, Molyneux ME, MacLennan CA 2010. Lymphocyte subsets in healthy Malawians: implications for immunologic assessment of HIV infection in Africa. J Allergy Clin Immunol 125: 203-208.

McCloskey TW, Cavaliere T, Bakshi S, Harper R, Fagin J, Kohn N, Pahwa S 1997. Immunophenotyping of T lymphocytes by threecolor flow cytometry in healthy newborns, children and adults. Clin Immunol Immunopathol 84: 46-55.

Pittet MJ, Speiser DE, Valmori D, Cerottini JC, Romero P 2000. Cytolytic effector function in human circulating $\mathrm{CD} 8^{+} \mathrm{T}$ cells closely correlates with CD56 surface expression. J Immunol 164: 1148-1152.

Poonia B, Pauza CD 2014. Levels of CD56 ${ }^{+}$TIM-3 - effector CD8 T cells distinguish HIV natural virus suppressors from patients receiving antiretroviral therapy. PLOS ONE 9: e88884.

Pozo-Rubio T, Capilla A, Mujico JR, de Palma G, Marcos A, Sanz Y, Polanco I, García-Novo MD, Castillejo G, Ribes-Koninckx C, Varea V, Palau F, Ortigosa L, Peña-Quintana L, Nova E 2013. Influence of breastfeeding versus formula feeding on lymphocyte subsets in infants at risk of coeliac disease: the PROFICEL study. Eur J Nutr 52: 637-646.

Sagnia B, Ndongo FA, Tetang SNM, Torimiro JN, Cairo C, Domkam I, Agbor G, Mve E, Tocke O, Fouda E, Oukem-Boyer OOM, Colizzi V 2011. Reference values of lymphocyte subsets in healthy, HIV-negative children in Cameroon. Clin Vaccine Immunol 18: 790-795. 
Shearer WT, Rosenblatt HM, Gelman RS, Oyomopito R, Plaeger S, Stiehm ER, Wara DW, Douglas SD, Luzuriaga K, McFarland EJ, Yogev R, Rathore MH, Levy W, Graham BL, Spector SA, Pediatric AIDS Clinical Trials Group 2003. Lymphocyte subsets in healthy children from birth through 18 years of age: the Pediatric AIDS Clinical Trials Group P1009 study. J Allergy Clin Immunol 112: 973-980.

Sommer F, Bäckhed F 2013. The gut microbiota - masters of host development and physiology. Nat Rev Microbiol 11: 227-238.

Sukwit S, Chuenchitra T, Rojanasang P, Wiwattanakul S, Saksopin L, Srisurapanon S 2005. Distribution of CD38 molecules on CD3 and $\mathrm{CD} 8^{+} \mathrm{T}$ lymphocyte in adulthood HIV-1-uninfected Thais. $J$ Med Assoc Thai 88 (Suppl. 1): S48-S55.

Tiba F, Nauwelaers F, Sangaré L, Coulibaly B, Kräusslich HG, Böhler $\mathrm{T}$ 2011. Activation and maturation of peripheral blood T cells in HIV-1-infected and HIV-1-uninfected adults in Burkina Faso: a cross-sectional study. J Int AIDS Soc 14: 57.

Tsegaye A, Wolday D, Otto S, Petros B, Assefa T, Alebachew T, Hailu E, Adugna F, Measho W, Dorigo W, Fontanet AL, van Baarle D,
Miedema F 2003. Immunophenotyping of blood lymphocytes at birth, during childhood and during adulthood in HIV-1-uninfected Ethiopians. Clin Immunol 109: 338-346.

Wiener D, Shah S, Malone J, Lowell N, Lowitt S, Rowlands Jr DT 1990. Multiparametric analysis of peripheral blood in the normal pediatric population by flow cytometry. J Clin Lab Anal 4: 175-179.

Yachie A, Miyawaki T, Nagaoki T, Yokoi T, Mukai M, Uwadana N, Taniguchi N 1981. Regulation of B cell differentiation by $\mathrm{T}$ cell subsets defined with monoclonal OKT4 and OKT8 antibodies in human cord blood. J Immunol 127: 1314-1317.

Yanase Y, Tango T, Okumura K, Tada T, Kawasaki T 1986. Lymphocyte subsets identified by monoclonal antibodies in healthy children. Pediatr Res 20: 1147-1151.

Zaccarelli-Filho CA, Ono E, Machado DM, Brunialti M, Succi RC, Salomão R, Kallás EG, de Moraes-Pinto MI 2007. HIV-1-infected children on HAART: immunologic features of three different levels of viral suppression. Cytometry B Clin Cytom 72: 14-21. 


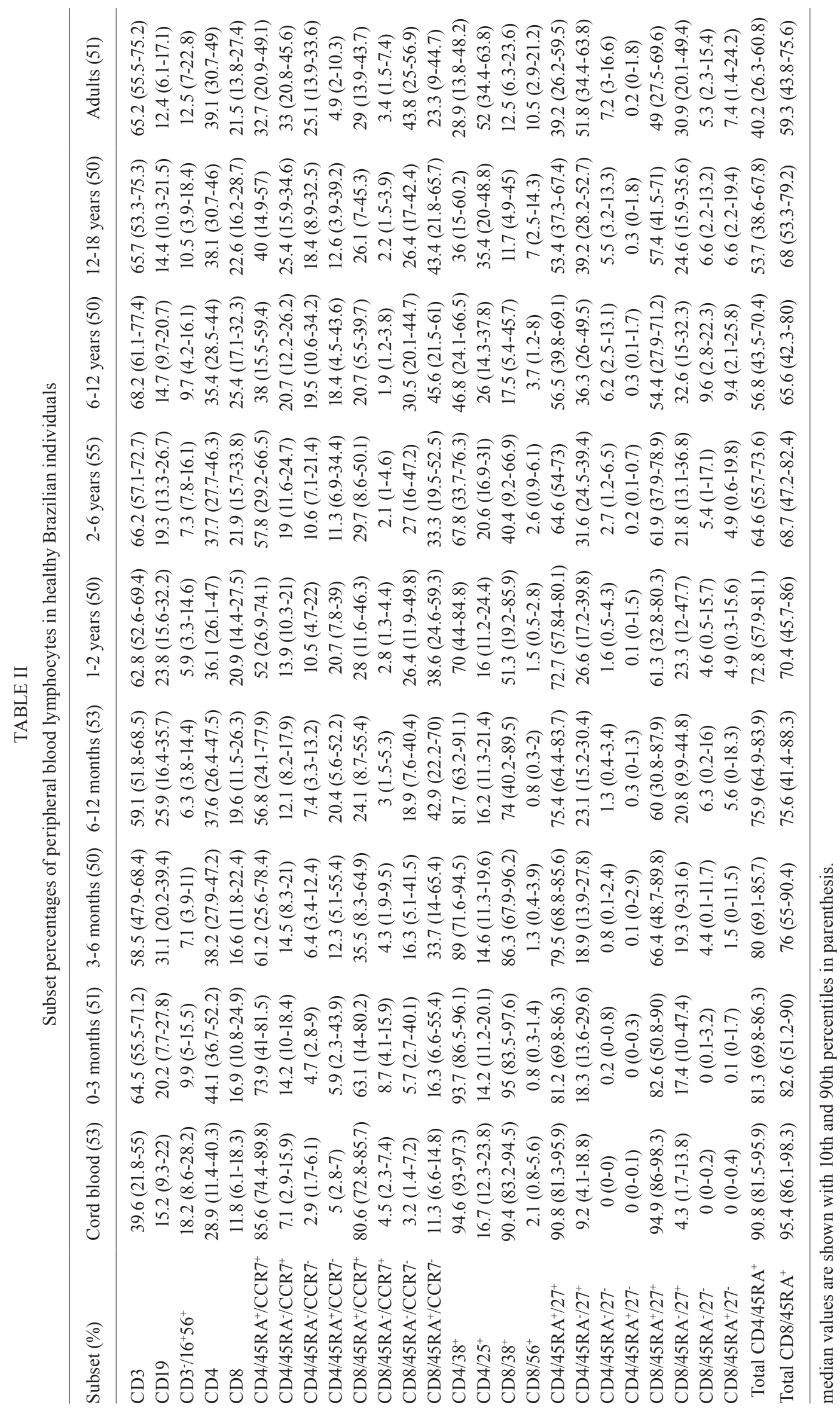




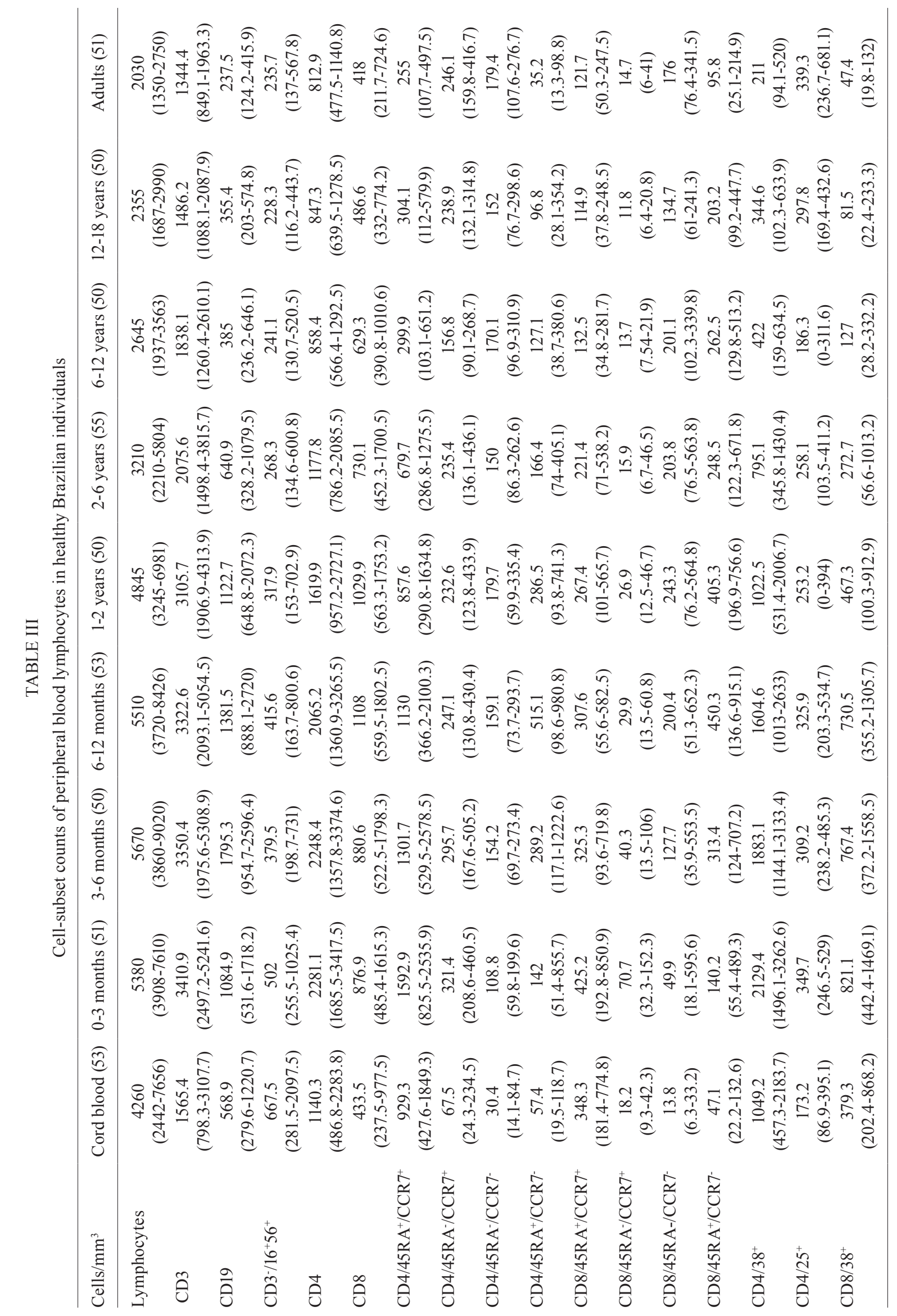




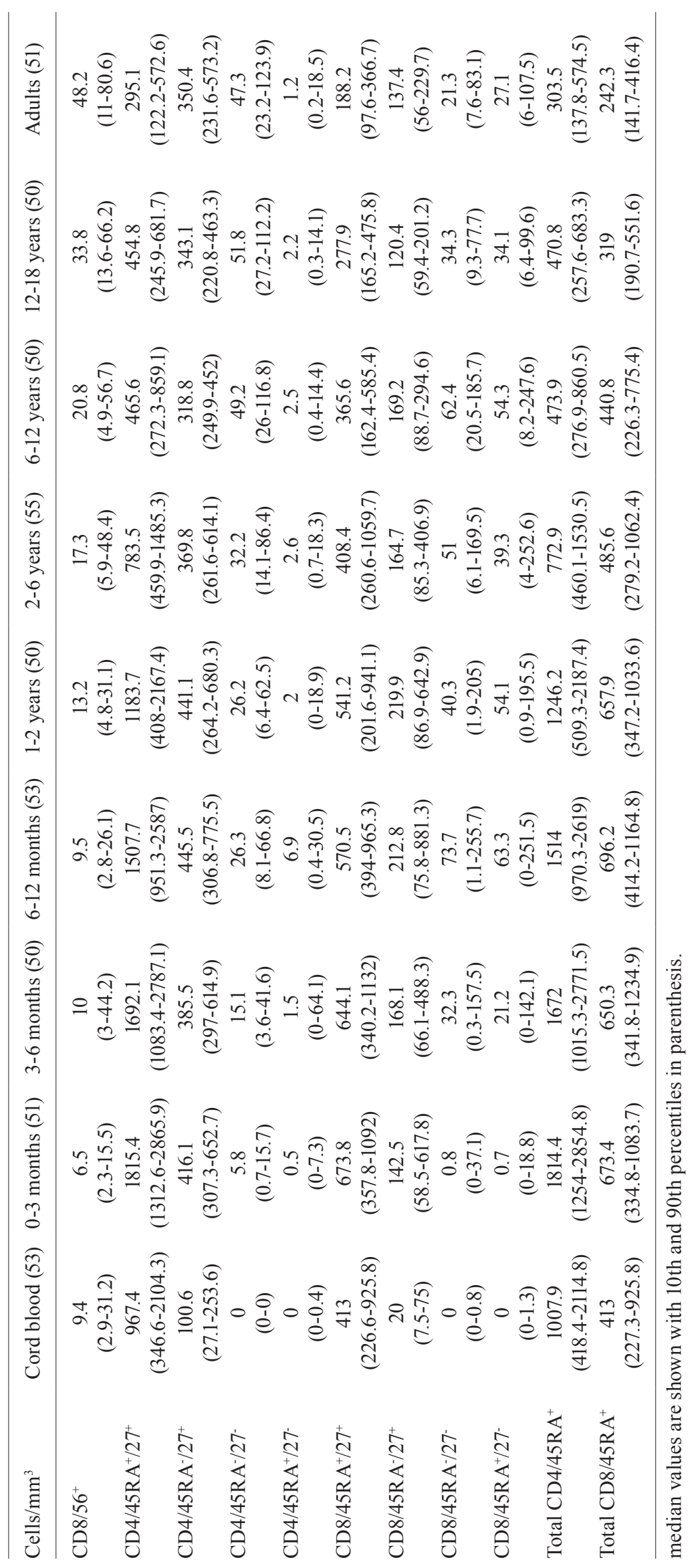

